\title{
Determinan Stunting pada Balita Usia 12-59 Bulan di Puskesmas Bojongsari Kota Depok
}

\author{
Ayu Wulansari ${ }^{1}$, Astrid Novita ${ }^{2}$ Herjanti $^{3}$ \\ ${ }^{1,2,3}$ Program Studi Kebidanan Program Sarjana Terapan Departemen Kebidanan \\ Sekolah Tinggi Ilmu Kesehatan Indonesia Maju \\ Jln. Harapan Nomor 50, Lenteng Agung, Jakarta Selatan 12610, Indonesia \\ Email: ${ }^{1}$ ayuwulansari0698@gmail.com
}

Editor: ALR
Diterima: 13/10/2021
Direview: 22/11/2021
Publish: 01/12/2021
Hak Cipta:
C2021 Artikel ini memiliki akses
terbuka dan dapat didistribusikan
berdasarkan ketentuan Lisensi
Atribusi Creative Commons, yang
memungkinkan penggunaan,
distribusi, dan reproduksi yang tidak
dibatasi dalam media apa pun, asalkan
nama penulis dan sumber asli
disertakan. Karya ini dilisensikan di
bawah Lisensi Creative Commons
Attribution Share Alike
Internasional.

\section{A B S T R A C T}

Introduction: Specifically for the 12-24 month age group, the report on the results of weighing children under five at the sub-district level in Depok City shows that the Depok sub-district is the sub-district that has the highest prevalence of stunting $(22.3 \%)$.

Objectives: This study aims to determine whether there is a relationship between birth weight, exclusive breastfeeding, immunization status, and infant and child feeding on the incidence of stunting in toddlers at the Bojongsari Health Center in 2021.

Method: Respondents in this study were mothers who had stunted toddlers aged 12-59 months who were located in the Bojongsari Health Center area. This research is quantitative research with the analytic method with a cross-sectional approach. The population taken by toddlers who experienced stunting amounted to 130 respondents and the number of samples was 97 respondents. The sampling technique used was the Lemeshow formula with purposive sampling. The types of data used are secondary and primary data with univariate and bivariate analysis. The data were processed using SPSS 25.

Result: The results of the Chi-square statistical test for birth weight variables $(p$-value $=0.027)$, exclusive breastfeeding $(p$-value $=0.038)$, immunization status $(\mathrm{p}$-value $=0.036)$ and infant feeding and child ( $\mathrm{p}$ value $=0.000$ ) .

Conclusion: There is a relationship between birth weight, exclusive breastfeeding, immunization status, and infant and child feeding on the incidence of stunting in toddlers aged 12-59 months at the Bojongsari Health Center, Depok City in 2021.

Keywords: birth weight, exclusive breastfeeding, stunting, toddler 


\section{Pendahuluan}

Kejadian balita stunting (pendek) merupakan masalah gizi utama yang dihadapi Indonesia. Menurut data pemantauan status gizi (PSG) tiga tahun terakhir, prevalensi stunting tertinggi dibandingkan dengan masalah gizi lainnya seperti gizi buruk, penurunan berat badan dan obesitas. Prevalensi anak stunting meningkat dari 27,5\% pada tahun 2016 menjadi 29,6\% pada tahun 2017. Pada tahun 2017, prevalensi anak sangat pendek dan pendek usia 0-59 bulan di Indonesia masing-masing sebesar 9,8\% dan 19,8\%. Keadaan ini mengalami peningkatan dibandingkan tahun sebelumnya yaitu prevalensi anak sangat pendek sebesar $8,5 \%$, sedangkan prevalensi anak pendek sebesar $19 \%$. Provinsi dengan prevalensi tertinggi anak sangat pendek dan pendek usia 0-59 bulan pada tahun 2017 adalah Nusa Tenggara Timur, sedangkan provinsi dengan prevalensi terendah adalah Bali. ${ }^{1}$

Sebagai negara terpadat di Asia Tenggara, Indonesia masih berjuang untuk menghilangkan ancaman stunting pada anak balita. Menurut data yang dirilis oleh UNICEF pada tahun 2017, Indonesia menempati peringkat kedua di ASEAN dalam prevalensi stunting pada tahun 2015. Indonesia hanya lebih baik dari Laos yang merupakan negara dengan kasus stunting terbanyak. Menurut data ASEAN tahun 2017, diantara balita Asia Tenggara, sebanyak 17,9 juta anak stunting atau kerdil, 5,4 juta lahir cacat fisik, 4,5 juta kelebihan berat badan, dan menderita anemia gizi buruk. ${ }^{2}$

Menurut Organisasi Kesehatan Dunia, jika prevalensinya mencapai 20\% atau lebih tinggi, prevalensi anak kecil yang pendek akan menjadi masalah kesehatan masyarakat. Oleh karena itu, proporsi balita stunting di Indonesia masih tinggi yang merupakan masalah kesehatan yang harus ditangani. Stunting merupakan salah satu masalah yang menghambat pembangunan manusia dalam skala global. Saat ini, ada sekitar 162 juta anak balita yang mengalami stunting. Jika tren ini terus berlanjut, diperkirakan pada tahun 2025, 127 juta balita akan mengalami stunting. Menurut United Nations Children's Emergency Fund (UNICEF) lebih dari setengah atau 56\% anak stunting tinggal di Asia, dan lebih dari sepertiga atau 37\% tinggal di Afrika. ${ }^{2}$

Hasil Kajian Kesehatan Dasar 2017 (2018) menunjukkan bahwa angka prevalensi stunting tahun 2017 sebesar 36,8\%, diantaranya 18,8\% tipe sangat pendek, 18,0\% tipe pendek, dan angka prevalensi stunting tahun 2013 sebesar 37,2\%. . Pada kategori sangat pendek terjadi peningkatan sebesar 18,0\%, dan pada kategori pendek bahkan meningkat sebesar 19,2\%. Pada saat yang sama, prevalensi stunting pada tahun 2018 adalah 30,8\%, termasuk 11,5\% spesies sangat pendek dan $19,3 \%$ spesies pendek. Hal ini menunjukkan bahwa prevalensi stunting turun sebesar 6\% dari tahun 2013 hingga $2018 .^{3}$

Berdasarkan data di Jawa Barat sendiri tercatat ada 29,9\% atau 2,7 juta balita yang terkena stunting. Menurut Gubernur, 13 kabupaten di Jabar akan diintervensi program stunting untuk memaksimalkan dampaknya. 13 wilayah di Jawa Barat dengan jumlah korban terbanyak yang disebutkan Emir antara lain Kabupaten Garut (43,2\%), Kabupaten Sukabumi (37,6\%), Kabupaten Cianjur (35,7\%), dan Kabupaten Tasikmalaya $(33,3) \%$. ), Kabupaten Bandung Barat (34,2\%), Kabupaten Bogor (28,29\%), Kabupaten Bandung (40,7\%), Kabupaten Kuningan (42\%), Kabupaten Cirebon (42,47\%), Bupati Sumedang (41,08\%), Kabupaten Indramayu (36,12\%), Kabupaten Subang (40,47\%), dan Kabupaten Karawang (34,87\%).

Dari data Dinkes Depok pada 2020 jumlah stunting mencapai 5.075 anak. Sedangkan pada 2019 angkanya mencapai 5.241 anak, di 2018 angka stunting mencapai 6.751 anak. 


\section{SIMFISIS Jurnal Kebidanan Indonesia}

Prevalensi stunting balita di Kota Depok lebih rendah dari angka nasional. Namun, pada tahun 2017 terjadi peningkatan prevalensi balita stunting dari 8,14\% (2015) menjadi 20,75\%. Khusus pada kelompok umur 12-24 bulan, laporan hasil penimbangan balita tingkat kelurahan di Kota Depok menunjukkan bahwa Kelurah Depok merupakan kelurahan yang memiliki prevalensi stunting tertinggi (22,3\%). Hal ini disebabkan tanpa intervensi dini, stunting akan terus berlanjut pengaruh buruk pada generasi berikutnya. ${ }^{5}$

Berdasarkan studi pendahuluan yang dilakukan peneliti dengan menggunakan wawancara terhadap 18 responden yang memiliki balita usia 12-59 bulan diketahui terdapat 4 orang diantaranya lahir dengan berat badan lahir rendah dikarenakan kurangnya status gizi ibu saat hamil dan riwayat BBLR sebelumnya, 6 orang tidak diberikan ASI eksklusif dikarenakan ASI tidak keluar pada saat anak lahir sehingga bayi diberikan susu formula sebagai pengganti. 5 orang diberikan makanan pendamping ASI secara dini atau tidak sesuai dengan masanya karena ibu mengatakan bayinya rewel, dan 3 orang tidak diimunisasi secara lengkap dikarenakan kurangnya pengetahuan tentang pentingnya imunisasi pada anak.

Tujuan penelitian ini untuk mengetahui berat badan lahir, pemberian asi eksklusif, status imunisasi dan pemberian makan bayi dan anak terhadap kejadian stunting pada balita di Puskesmas Bojongsari tahun 2021.

\section{Metode}

Penelitan ini termasuk dalam penelitian kuantitatif dengan desain penelitian cross sectional yang bersifat analitik. Tujuannya untuk mengetahui hubungan berat badan lahir, pemberian asi eksklusif, status imunisasi dan pemberian makan bayi dan anak terhadap kejadian stunting pada balita. ${ }^{6}$ Lokasi penelitian dilakukan di Puskesmas Bojongsari pada bulan febuari 2021 .

Populasi pada penelitian ini adalah balita yang mengalami stunting yang terdapat di Kelurahan Serua Kecamatan Bojongsari yang berjumlah 130 orang. Sampel dalam penelitian ini adalah sebagian balita stunting yang diambil dengan teknik purposive sampling dengan rumus lemeshow didapatkan sampel berjumlah 97 responden. Instrumen penelitian yang digunakan dalam penelitian ini berupa kuesioner. ${ }^{7}$ Pengumpulan informasi dilakukan setelah ibu bersedia untuk dibuat sebgaai sampel dalam penelitian ini. Ibu kemudian diminta untuk mengisi kuesioner yang telah dibuat atau disediakan dengan lengkap. Uji coba kuesioner hubungan berat badan lahir, pemberian asi eksklusif, status imunisasi dan pemberian makan bayi dan anak terhadap kejadian stunting pada balita dilakukan kepada 20 responden.

Validitas item yang akan dipakai untuk mengukur apa yang ingin diukur, atau bisa dilaksanakan dengan penilaian dengan cara metode korelasi person atau metode corrected item total corelation. Metode uji validitas ini dengan cara mengkorelasikan masing-masing skor total item. Skor total item dengan penjumlahan dari keseluruhan item. Pengujian validitas instrumen dilakukan dengan menggunakan SPSS Statistik. Berdasarkan uji validitasi pertanyaan variabel stunting yang dilakukan di Puskesmas Bojongsari Kota Depok didapatkan hasil dari 5 pertanyaan tersebut dinyatakan valid, pertanyaan variabel berat badan lahir yang dilakukan di Puskesmas Bojongsari Kota Depok didapatkan hasil dari pertanyaan tersebut dinyatakan valid, pertanyaan pemberian asi eksklusif yang dilakukan di Puskesmas Bojongsari Kota Depok didapatkan hasil dari 4 pertanyaan tersebut dinyatakan valid, pertanyaan variabel status imunisasi yang dilakukan di Puskesmas Bojongsari Kota Depok didapatkan hasil dari pertanyaan tersebut dinyatakan valid, pertanyaan variabel pemberian makan bayi dan anak 
yang dilakukan di Puskesmas Bojongsari Kota Depok didapatkan hasil dari 15 pertanyaan tersebut dinyatakan valid. Berdasarkan hasil uji reliabilitas pada variabel stunting, berat badan lahir, pemberian asi eksklusif, status imunisasi dan pemberian makan bayi dan anak didapatkan hasil pada masing-masing variabel dikatakan reliabel karena Cronbach Alpha > R Tabel.

Kriteria Inklusi dalam penelitian ini adalah: anak balita yang mengalami stunting, anak balita yang tinggal di Kelurahan Serua Kecamatan Bojongsari, anak balita yang mempunyai ibu yang tidak cacat mental, anak balita yang di asuh oleh ibunya sendiri. Kriteria non inklusi : balita yang bukan berada di Kelurahan Serua Kecamatan Bojongsari. Analisis data yang di gunakan dalam penelitian ini adalah Analisis Univariat dan Analisis Bivariat. Dengan pengujian korelasi untuk mengetahui antar variabel dependen dengan variabel independen. Pembuktiannya menggunakan metode Chi-Square, metode ini dipilih karena dua variabel merupakan variabel kategori. Prinsip pengujian Chi-Square ini adalah dengan membandingkan frekuensi terjadi (observasi) dengan frekuensi harapan (espektasi). Peneliti menggunakan uji Chi-Square dengan tingkat kepercayaan $95 \%$. Bila nilai $p$-value $\leq 0,05$ berarti hasil perhitungan statistik bermakna dan apabila $p$-value $>0,05$ berarti hasil perhitungan statistik tidak bermakna. Penyajian hasil pengolahan data dengan menggunakan tabel dan naratif.

\section{Hasil}

\section{Analisis Univariat}

Tabel 1. Distribusi Frekuensi Kejadian Stunting, Berat Badan Lahir, Pemberian Asi Eksklusif, Status Imunisasi dan Pemberian Makan Bayi dan Anak Terhadap Kejadian Stunting pada Balita di Puskesmas Bojongsari Tahun 2021.

\begin{tabular}{lcc}
\hline Variabel & Frekuensi (f) & Persentase (\%) \\
Stunting & 33 & 34,0 \\
Stunting Berat & 64 & 66,0 \\
Stunting Ringan & & \\
Berat Badan Lahir & 54 & 55,7 \\
BBLR & 43 & 44,3 \\
Normal & 49 & 50,5 \\
Pemberian Asi Eksklusif & 48 & 49,5 \\
Tidak Asi Eksklusif & & \\
Asi Eksklusif & 43 & 44,3 \\
Status Imunisasi & & 55,7 \\
Imunisasi Tidak & 54 & 48,5 \\
Lengkap & & 51,5 \\
Imunisasi Lengkap & 47 & \\
Pemberian Makan Bayi dan Anak & 50 & \\
Kurang Baik & &
\end{tabular}

Berdasarkan Tabel 1 didapatkan bahwa dari 97 responden paling banyak mengalami stunting ringan di Puskesmas Bojongsari yaitu sebanyak 64 (66,0\%) responden, paling banyak balita yang mengalami BBLR yaitu sebanyak $54(55,7 \%)$ responden, paling banyak balita yang tidak ASI eksklusif yaitu sebanyak 49 (50,5\%) responden, paling banyak balita yang imunisasi lengkap yaitu sebanyak $54(55,7 \%)$ responden, dan paling banyak balita dengan pemberian makan baik yaitu sebanyak $50(51,5 \%)$ responden.

\section{Analisis Bivariat}

Analisa bivariat adalah analisa untuk mengetahui hubungan antara variabel independen 


\section{SIMFISIS Jurnal Kebidanan Indonesia}

Volume 01, Nomor 02, November 2021

(berat badan lahir, pemberian asi eksklusif, status imunisasi dan pemberian makan bayi dan anak) dan variabel dependen (kejadian stunting). Dengan jumlah sampel responden sebesar 97 responden, data disajikan dalam bentuk tabel dan naratif sebagai berikut :

Tabel 2. Hasil Uji Crosstab Determinan Stunting pada Balita Usia 12-59 Bulan di Puskesmas Bojongsari Kota Depok

\begin{tabular}{|c|c|c|c|c|c|c|c|c|}
\hline \multirow{3}{*}{ Variabel } & \multicolumn{6}{|c|}{ Kejadian Stunting } & \multirow{3}{*}{ P-Value } & \multirow{3}{*}{ OR } \\
\hline & \multicolumn{2}{|c|}{ Stunting Berat } & \multicolumn{2}{|c|}{ Stunting Ringan } & \multicolumn{2}{|c|}{ Total } & & \\
\hline & $\mathbf{F}$ & $\%$ & $\mathbf{F}$ & $\%$ & $\mathbf{F}$ & $\%$ & & \\
\hline \multicolumn{9}{|l|}{ Berat Badan lahir } \\
\hline BBLR & 24 & 24,7 & 30 & 30,9 & 54 & 100,0 & \multirow{2}{*}{0,027} & \multirow{2}{*}{3,022} \\
\hline Normal & 9 & 9,3 & 34 & 35,1 & 43 & 100,0 & & \\
\hline \multicolumn{9}{|l|}{ Pemberian Asi } \\
\hline Eksklusif & & & & & & & \multirow{3}{*}{0,038} & \\
\hline Tidak Asi Eksklusif & 22 & 22,7 & 27 & 27,8 & 49 & 100,0 & & \multirow{2}{*}{2,741} \\
\hline Asi Eksklusif & 11 & 11,3 & 37 & 38,1 & 48 & 100,0 & & \\
\hline \multicolumn{9}{|l|}{ Status Imunisasi } \\
\hline $\begin{array}{l}\text { Imunisasi Tidak } \\
\text { Lengkap }\end{array}$ & 20 & 20,6 & 23 & 23,7 & 43 & 100,0 & \multirow{2}{*}{0,036} & \multirow{2}{*}{2,742} \\
\hline Imunisasi Lengkap & 13 & 13,4 & 41 & 42,3 & 54 & 100,0 & & \\
\hline \multicolumn{9}{|l|}{$\begin{array}{l}\text { Pemberian Makan } \\
\text { Bayi dan Anak* }\end{array}$} \\
\hline Kurang Baik & 22 & 22,7 & 25 & 25,8 & 47 & 100,0 & \multirow{2}{*}{0,000} & \multirow{2}{*}{3,120} \\
\hline Baik & 11 & 11,3 & 39 & 40,2 & 50 & 100,0 & & \\
\hline
\end{tabular}

Berdasarkan Tabel 2 Hubungan Berat Badan lahir Terhadap kejadian Stunting Pada Balita didapatkan bahwa dari 97 responden terdapat 54 responden yang berat badan lahir rendah (BBLR), dimana 24 responden $(24,7 \%)$ mengalami kejadian stunting berat, dan 30 responden $(30,9 \%)$ mengalami kejadian stunting ringan. Hasil uji statistik menggunakan chi-square di dapatkan nilai $p$-value $=0,027(\rho<0.05)$ artinya Ho ditolak dan Ha diterima, artinya ada hubungan berat badan lahir terhadap kejadian stunting pada balita di Puskesmas Bojongsari Tahun 2021 dengan odds ratio $=3,022$ artinya balita yang mengalami berat badan lahir rendah berpeluang 3,0 kali mengalami kejadian stunting ringan dibanding dengan balita yang mengalami berat badan lahir normal.

Berdasarkan Tabel 2 hubungan pemberian asi eksklusif terhadap kejadian stunting pada balita didapatkan bahwa dari 97 responden terdapat 49 responden yang tidak asi eksklusif, dimana 22 responden $(22,7 \%)$ mengalami kejadian stunting berat, dan 27 responden $(27,8 \%)$ mengalami kejadian stunting ringan Hasil uji statistik menggunakan chi-square di dapatkan nilai $p$-value $=0,038(\rho<0.05)$ artinya Ho ditolak dan Ha diterima, artinya ada hubungan pemberian asi eksklusif terhadap kejadian stunting pada balita di Puskesmas Bojongsari Tahun 2021 dengan odds ratio $=2,741$ artinya balita yang tidak asi eksklusif berpeluang 2,7 kali mengalami kejadian stunting ringan dibanding dengan balita yang asi eksklusif.

Berdasarkan Tabel 2 Hubungan Status Imunisasi Terhadap kejadian Stunting Pada Balita didapatkan bahwa dari 97 responden terdapat 54 responden yang imunisasi lengkap, dimana 13 responden $(13,4 \%)$ mengalami kejadian stunting berat dan 41 responden $(42,3 \%)$ mengalami kejadian stunting ringan. Hasil uji statistik menggunakan chi-square di dapatkan nilai $p$-value $=0,036(\rho<0.05)$ artinya Ho ditolak dan Ha diterima, artinya ada hubungan status imunisasi terhadap kejadian stunting pada balita di Puskesmas Bojongsari Tahun 2021 dengan odds ratio $=2,742$ artinya balita yang melakukan imunisasi lengkap berpeluang 2,7 
kali mengalami kejadian stunting ringan dibanding dengan balita yang tidak melakukan imunisasi lengkap.

Berdasarkan Tabel 2 hubungan pemberian makan bayi dan anak terhadap kejadian stunting pada balita didapatkan bahwa dari 97 responden terdapat 50 responden pemberian makan dengan baik, dimana 11 (11,3\%) mengalami stunting berat dan 39 (40,2\%) yang mengalami stunting ringan . Hasil uji statistik menggunakan chi-square di dapatkan nilai $p$ value $=0,000(\rho<0.05)$ artinya Ho ditolak dan Ha diterima, artinya ada hubungan pemberian makan bayi dan anak terhadap kejadian stunting pada balita di Puskesmas Bojongsari Tahun 2021 dengan odds ratio $=3,120$ artinya pemberian makan bayi dan anak dengan baik berpeluang 3,1 kali mengalami kejadian stunting ringan dibanding dengan pemberian makan bayi dan anak dengan kurang baik

\section{Pembahasan}

Keterbatasan yang dapat mempengaruhi penelitian. Keterbatasan - keterbatasaan tersebut antara lain Keterhambatan konsul dikarenakan konsul online karena pandemi covid 19, adanya Keterbatasan penelitian yaitu hanya dengan mengobservasi data sekunder berdasarkan buku status pasien yang dilakukan dengan cara bedah status dan mengambil beberapa data yang terdapat di buku status pasien, sehingga pengambilan data membutuhkan waktu yang cukup lama. Kurang lengkapnya data membuat peneliti harus menunggu kembali data untuk dapat diambil, peneliti kesulitan dalam membagikan kuesioner karena pandemic covid 19, dan penelitian kesulitan mencari referensi dalam penyusunan Skripsi ini sehingga dalam hal ini penulis menambah materi dari teori dengan mencari referensi dari berbagai buku dan jurnal.

\section{Hubungan Berat Badan Lahir Terhadap Kejadian Stunting pada Balita di Puskesmas Bojongsari Tahun 2021}

Berdasarkan Tabel 2 hubungan berat badan lahir terhadap kejadian stunting pada balita didapatkan bahwa dari 97 responden terdapat 54 responden yang berat badan lahir rendah (BBLR), dimana 24 responden $(24,7 \%)$ mengalami kejadian stunting berat, dan 30 responden $(30,9 \%)$ mengalami kejadian stunting ringan.

Hasil uji statistik menggunakan chi-square di dapatkan nilai $p$-value $=0,027(\rho<0.05)$ artinya Ho ditolak dan Ha diterima, artinya ada hubungan berat badan lahir terhadap kejadian stunting pada balita di Puskesmas Bojongsari Tahun 2021 dengan odds ratio $=3,022$ artinya balita yang mengalami berat badan lahir rendah berpeluang 3,0 kali mengalami kejadian stunting ringan dibanding dengan balita yang mengalami berat badan lahir normal.

Menurut penelitian Maria Nova, Hasil uji menggunakan uji Chi-Square diperoleh nilai $\mathrm{p}=0,002<(\boldsymbol{\alpha}=0,05)$ hal ini membuktikan bahwa ada hubungan yang signifikan antara berat badan lahir anak dan kejadian stunting usia 24-59 bulan di wilayah kerja Puskesmas Kota Lubuk Buaya. Dimana digambarkan pada hasil penelitian ini berat badan lahir normal sebesar 88,8\% di Wilayah Kerja Puskesmas Lubuk Buaya Kota Padang. ${ }^{8}$

Selanjutnya pada jurnal Anisa mengenai hubungan berat badan lahir dengan kejadian stunting di Puskesmas Sonder memberikan kesimpulan bahwa terdapat hubungan yang signifikan antara berat badan lahir dengan kejadian stunting dengan nilai $\mathrm{p}=0,001(\mathrm{P}<0,05) .{ }^{9}$

Hal yang sama juga diperoleh Nasution (2014) berat badan lahir berhubungan angka kejadian stunting pada anak usia 6-24 bulan 5,6 kali lebih tinggi stunting. ${ }^{10}$ Lalu pada jurnal 
Suryo menjelaskan terdapat hubungan secara signifikan antara berat badan lahir dengan kejadian stunting pada balita. Didapatkan hasil $\mathrm{p}=0,001$ dan mempunyai resiko 2,7 kali lebih besar mengalami stunting. Penelitian ini sejalan dengan penelitian yang dilakukan oleh Taguri yang menyatakan: berat badan lahir rendah secara signifikan terkait dengan morbiditas keterlambatan perkembangan pada anak kecil. ${ }^{11}$

Dari hasil yang didapatkan dari penelitian di Puskesmas Bojongsari penulis berpendapat bahwa berat badan lahir berhubungan dengan kejadian stunting dimana berat badan lahir berkaitan dengan status gizi ibu saat mengandung karena saat anak dalam kandungannya, ia hanya mendapat makanan dari ibunya. Ukuran bayi usia kehamilannya sangat kecil karena dia tidak bisa berkembang di dalam kandungan.

\section{Hubungan Pemberian ASI Ekslusif Terhadap Kejadian Stunting pada Balita di Puskesmas Bojongsari Tahun 2021}

Berdasarkan Tabel 2 Hubungan Pemberian ASI Eksklusif Terhadap kejadian Stunting Pada Balita didapatkan bahwa dari 97 responden terdapat 49 responden yang tidak asi eksklusif, dimana 22 responden (22,7\%) mengalami kejadian stunting berat, dan 27 responden $(27,8 \%)$ mengalami kejadian stunting ringan. Hasil uji statistik menggunakan chi-square di dapatkan nilai $p$-value $=0,038(\rho<0.05)$ artinya Ho ditolak dan Ha diterima, artinya ada hubungan pemberian asi eksklusif terhadap kejadian stunting pada balita di Puskesmas Bojongsari Tahun 2021 dengan odds ratio $=2,741$ artinya balita yang tidak asi eksklusif berpeluang 2,7 kali mengalami kejadian stunting ringan dibanding dengan balita yang asi eksklusif.

Penelitian ini sejalan dengan penelitian Hidayah di daerah Purworejo Jawa Tengah, menyimpulkan bahwa Pemberian ASI Eksklusif berhubungan secara bermakna dengan kejadian Sunting $(\mathrm{p}=0,03$; OR=1,74) sehingga dapat disimpulkan anak yang tidak mendapat asi eklsusif berisiko 1,74 kali dibandingkan anak yang mendapatkan asi ekslusif atau resiko stunting meningkat 74\% pada anak yang tidak mendapatkan asi eksklusif. Hal ini menunjukkan anak yang diberikan asi eksklusif dapat mencapai pertumbuhannya dengan baik dibandingkan dengan yang tidak diberikan asi eksklusif, karena anak yang disusui secara ekslusif selama enam bulan akan memperoleh asupan asi yang cukup, baik dari volume/kwantitas asi maupun kwalitas zat gizinya sesuai dengan kebutuhan bayi. ${ }^{12}$

Hal Ini konsisten dengan penelitian Rambita dan ada hubungan yang diketahui antara keduanya hubungan riwayat pemberian ASI eksklusif dengan kejadian stunting pada balita di wilayah kerja Puskesmas Kawangkoan Kabupaten Minahasa dengan diperoleh nilai $p=0,004$ $(\mathrm{p}<0,05)$. Sehubungan juga dengan penelitian dari Putra (2017), terdapat hubungan yang bermakna antara pemberian asi eksklusif dengan kejadian stunting pada balita diperoleh nilai $\mathrm{p}=0,001(\mathrm{p}<0,05){ }^{13}$

Selanjutnya sesuai dengan penelitian yang dilakukan oleh Astri memberikan kesimpulan bahwa terdapat hubungan pemberian asi eksklusif dengan kejadian stunting pada balita usia 1-5 tahun. Dimana diperoleh $p$-value $=0,021(0,021<0,05) .{ }^{14}$

Penulis berpendapat bahwa pemberian asi eksklusif berhubungan dengan kejadian stunting karena asi merupakan makanan ideal untuk bayi sehingga pemberian asi eksklusif dianjurkan selama masih mencukupi kebutuhan bayi. Waktu menyusui menurut WHO, ini adalah 6 bulan, tetapi ini bukan tugas yang mudah terbukti dari sampel dalam penelitian ini tidak ada pemberian ASI eksklusif. 


\section{Hubungan Status Imunisasi Terhadap Kejadian Stunting pada Balita di Puskesmas Bojongsari Tahun 2021}

Berdasarkan Tabel 2 hubungan status imunisasi terhadap kejadian stunting pada balita didapatkan bahwa dari 97 responden terdapat 54 responden yang imunisasi lengkap, dimana 13 responden $(13,4 \%)$ mengalami kejadian stunting berat dan 41 responden $(42,3 \%)$ mengalami kejadian stunting ringan. Hasil uji statistik menggunakan chi-square di dapatkan nilai $p$-value $=0,036(\rho<0.05)$ artinya Ho ditolak dan Ha diterima, artinya ada hubungan status imunisasi terhadap kejadian stunting pada balita di Puskesmas Bojongsari Tahun 2021 dengan odds ratio $=2,742$ artinya balita yang melakukan imunisasi lengkap berpeluang 2,7 kali mengalami kejadian stunting ringan dibanding dengan balita yang tidak melakukan imunisasi lengkap.

Menurut penelitian Agus hasil penelitian terlihat bahwa proporsi anak balita yang mengalami stunting sebesar 29,2\% karena perolehan imunisasi yang tidak lengkap. Sedangkan proporsi anak balita yang keadaan gizinya normal sebesar $89.6 \%$ karena perolehan imunisasi yang lengkap. Hasil uji statsitik diperoleh nilai $\mathrm{p}=0,040(\mathrm{p}<0,05)$ sehingga Ho ditolak dan $\mathrm{Ha}$ diterima, hal ini berarti bahwa kejadian stunting pada balita di Kota Banda Aceh disebabkan oleh imunisasi yang tidak lengkap. ${ }^{15}$

Penelitian yang dilakukan oleh Farahdili di Wilayah Kerja Puskesmas Sukamajaya, dimana terdapat hubungan antara pemberian imunisasi dengan kejadian stunting, diperoleh nilai $\mathrm{p}=0.017$ yang berarti lebih kecil dari $\alpha=0.05$. $^{16}$

Penulis berpendapat bahwa status imunisasi terkait dengan keterlambatan perkembangan karena kekebalan memiliki efek kekebalan pada tubuh manusia, itu perlu apalagi di masa kanak-kanak, ini adalah usia dimana penyakit rentan. Dampak beberapa penyakit predisposisi adalah malnutrisi. Itulah sebabnya kelengkapan imunisasi berpengaruh signifikan terhadap stunting.

\section{Hubungan Pemberian Makan Bayi dan Anak Terhadap Kejadian Stunting pada Balita di Puskesmas Bojongsari Tahun 2021}

Berdasarkan Tabel 2 Hubungan Pemberian Makan Bayi dan Anak Terhadap kejadian Stunting Pada Balita didapatkan bahwa dari 97 responden terdapat 50 responden pemberian makan dengan baik, dimana $11(11,3 \%)$ mengalami stunting berat dan $39(40,2 \%)$ yang mengalami stunting ringan . Hasil uji statistik menggunakan chi-square didapatkan nilai $p$ value $=0,000(\rho<0.05)$ artinya Ho ditolak dan Ha diterima, artinya ada hubungan pemberian makan bayi dan anak terhadap kejadian stunting pada balita di Puskesmas Bojongsari Tahun 2021 dengan odds ratio $=3,120$ artinya pemberian makan bayi dan anak dengan baik berpeluang 3,1 kali mengalami kejadian stunting ringan dibanding dengan pemberian makan bayi dan anak dengan kurang baik.

Menurut penelitian Desiansi menunjukkan bahwa terdapat hubungan antara pemberian makan dengan kejadian stunting pada anak usia 1-2 tahun dengan nilai $(\mathrm{p}=0,000)$ dan nilai koefisien relasi $(\mathrm{R}=2,037)$. Nutrisi yang baik sangat penting untuk pertumbuhan anak-anak. Memberi makan adalah proses belajar perkenalkan berbagai jenis makanan kepada anak. Perilaku respons di beberapa negara, feeding rate masih sangat rendah dan dianggap sebagai kontribusi lawan malnutrisi. ${ }^{17}$

Hasil ini sejalan dengan penelitian yang dilakukan oleh Rita Sari dan Apri 


\section{SIMFISIS Jurnal Kebidanan Indonesia}

Volume 01, Nomor 02, November 2021

Sulistianingsih bahwa hasil penelitian ada (46\%) balita usia 2-5 tahun dalam kondisi stunting (pendek). Risiko pemberian makan orang tua yang tidak tepat adalah 18,0 kali risikonya dibandingkan dengan balita orang tuanya, beberapa balita mengalami keterlambatan perkembangan memiliki pola makan yang baik. Didukung oleh penelitian yang dilakukan Perdani, 2016 hasil analisis hubungan praktik pemberian makan dengan kejadian stunting anak usia 3-5 tahun diperoleh bahwa mayoritas orang tua kurang optimal dalam pemberian makan pada anaknya, orang tua yang optimal dalam pemberian makan pada anak mempunyai hubungan dengan kejadian stunting $p$-value $=0,000 .^{18}$

Penulis berpendapat bahwa pemberian makan bayi dan anak terkait efek samping perkembangan, di mana pola makan yang baik sangat penting untuk pertumbuhan anak- anak. Memberi makan bayi dan anak adalah proses belajar perkenalkan berbagai jenis makanan kepada anak Anda. Perilaku respon di beberapa negara, feeding rate masih sangat rendah dan dianggap sebagai kontribusi lawan malnutrisi.

\section{Kesimpulan}

Berdasarkan hasil penelitian dan pembahasan diatas, dapat disimpulkan bahwa dari 97 responden paling banyak mengalami stunting ringan di Puskesmas Bojongsari yaitu sebanyak $64(66,0 \%)$ responden. Dari 97 responden paling banyak balita yang mengalami BBLR yaitu sebanyak $54(55,7 \%)$ responden. Dari 97 responden paling banyak balita yang tidak asi eksklusif yaitu sebanyak $49(50,5 \%)$ responden. Dari 97 responden paling banyak balita yang imunisasi lengkap yaitu sebanyak $54(55,7 \%)$ responden. Dari 97 responden paling banyak balita dengan pemberian makan baik yaitu sebanyak $50(51,5 \%)$ responden. Ada hubungan berat badan lahir dengan kejadian stunting pada balita dengan nilai $p$-value 0,027 dan nilai OR 3,022, ada hubungan pemberian asi eksklusif terhadap kejadian stunting pada balita dengan nilai $p$-value 0,038 dan nilai OR 2,741, ada hubungan status imunisasi dengan kejadian stunting pada balita dengan nilai $p$-value 0,036 dan nilai OR 2,742, dan ada hubungan pemberian makan bayi dan anak dengan kejadian stunting pada balita dengan nilai $p$-value 0,000 dan nilai OR 3,120.

\section{Konflik Kepentingan}

Peneliti menyatakan bahwa penelitian ini independen dari konflik kepentingan individu dan organisasi.

\section{Ucapan Terima Kasih}

Terimakasih kepada seluruh pihak yang telah berkontribusi membantu proses penelitian ini.

\section{Pendanaan}

Sumber pendanaan diperoleh dari peneliti.

\section{Daftar Pustaka}

1. RI K. Buku Saku Pemantauan Status Gizi dan Indikator Kinerja Gizi Tahun 2015. Jakata Direktorat Gizi Masy Direktorat Jenderal Kesehat Masy Kementeri Kesehat RI. Published online 2016.

2. Welle D. UNICEF: 115 juta anak laki-laki di dunia menikah di bawah umur. Published online October 2020.

3. Riskesdas K. Hasil Utama Riset Kesehata Dasar (RISKESDAS). J Phys A Math Theor. 2018;44(8):1-200.

4. Dinas Kesehatan Provinsi Jawa Barat. Profil Kesehatan Dinas Kesehatan Provinsi Jawa Barat 2017. Disk Jabarprov. Published online 2017:52. 


\section{SIMFISIS Jurnal Kebidanan Indonesia}

Volume 01, Nomor 02, November 2021

5. Kesehatan D, Depok K, Kesehatan D, Depok K. DINAS KESEHATAN KOTA DEPOK TAHUN 2018.

6. Wahyuni D. PERTARUNGAN JURNALISME DAN SASTRA DALAM MENGUAK KEBENARAN. Paradig J Kaji Budaya. 2019;9(3):231-255.

7. Morissan. Buku_Metode_Penelitian_Survei_Morissan.Pdf. Published online 2012:166.

8. Nova M, Afriyanti O. Hubungan berat badan, asi eksklusif, mp-asi dan asupan Energi dengan stunting pada balita usia 24-59 bulan Di puskesmas lubuk buaya. J Kesehat PERINTIS (Perintis's Heal Journal). 2018;5(1):39-45.

9. Selvia A, Amru DE. Efektifitas Media Promosi Kesehatan terhadap Peningkatan Pengetahuan, Sikap dan Perilaku Ibu Hamil Melakukan Kunjungan Antenatal Care. J Bidan Komunitas. 2020;3(3):132-144. doi:10.33085/jbk.v3i3.4716

10. Winowatan G, Malonda NSH, Punuh MI. Hubungan antara berat badan lahir anak dengan kejadian stunting pada anak batita di wilayah kerja puskesmas sonder kabupaten Minahasa. KESMAS. 2017;6(3).

11. Nova A. Faktor Yang Mempengaruhi Pernikahan Usia Dini Di Desa Baru Kabupaten Kerinci. J Endur Progr Stud Kesehat Masy STIKes Syedza Saintika Padang. 2019;4(3):470.

12. Rohmah FN, Arifah S. OPTIMALISASI PERAN KADER KESEHATAN DALAM DETEKSI DINI STUNTING. BEMAS J Bermasyarakat. 2021;1(2):95-102.

13. Ticoalu TW. Pemberdayaan media massa dalam meningkatkan pendidikan politik pada masyarakat kelurahan wewelen kecamatan tondano barat kabupaten minahasa. e-journal Acta Diurna Univ Sam Ratulangi Manad. 2015;IV(3):1-15.

14. Margawati A, Astuti AM. Pengetahuan ibu, pola makan dan status gizi pada anak stunting usia 1-5 tahun di Kelurahan Bangetayu, Kecamatan Genuk, Semarang. J Gizi Indones (The Indones J Nutr. 2018;6(2):8289. doi:10.14710/jgi.6.2.82-89

15. Al Rahmad AH. Pemberian ASI dan MP-ASI terhadap pertumbuhan bayi usia 6-24 bulan. J Kedokt Syiah Kuala. 2017;17(1):4-14.

16. Sagita YD, Lusi S. Kualitas pelayanan antenatal care (ANC) dan tingkat kepuasan ibu hamil. J Wellness Heal Mag. 2019;1(1):23-28.

17. Olii REP, Satriyandari Y, Ernawati D. HUBUNGAN POLA PEMBERIAN MAKAN DENGAN KEJADIAN STUNTING PADA BALITA USIA 2-5 TAHUN DI WILAYAH KERJA PUSKESMAS MINGGIR KABUPATEN SLEMAN. Published online 2019.

18. Widyastuti RH. Gambaran beban keluarga dalam merawat lansia dengan demensia di kelurahan Pancoranmas, Depok, Jawa Barat: Studi Fenomenologi. J Kesehat (The J Heal Vol 1 no 7 Juni 2011 hal 53-57. 2011;1(7):53-57. 